\title{
A TALE OF TWO RUSHANS: ARCHITECTURE THROUGH ORAL HISTORY
}

\author{
H.M. ABBAS \\ Architecture Department at Effat University, Jeddah, KSA.
}

\begin{abstract}
The Hijaz, in the western Arabian Peninsula, is a cultural hub where Muslims of different backgrounds gather, accounting for its unity and diversity. As any other surrounding region, modernity has touched the Hijaz in various forms, especially in its material culture. In Jidda, the main coastal city in the region, traditional domestic buildings, built mainly in the early 1800 s, were inhabited by their owners until the oil boom in the1970s. When these families left their homes, in many cases, the owners rented them to low-income labourers, rented them as shops or simply left them empty. In all cases, the majority of houses in Old Jidda were victims of misuse and neglect. In order to understand the original structures of these houses, I interviewed their owners, most of whom, luckily, are still alive. The purpose of the study is to document the existing status of two surviving houses from Old Jidda and to analyse their interior spaces through interviewing people who used to live in them. The aim of this study was to create a link between the existing architectural elements of the selected houses and the houses' oral history, which is achieved through interviewing the owners. The selected properties are Bayt al-Jukhdar and Bayt Nur Wali. These were selected because they witnessed minor changes since they became unoccupied in the 1970s. The result that this study should achieve is a documentation of the structure, architectural elements, interior divisions and details together with people's experience of living in these traditional houses.
\end{abstract}

Keywords: domestic architecture, Hijaz, Jidda, oral history, rushan.

\section{INTRODUCTION}

Djidda is well built; indeed better than any Turkish town of equal size that I had hitherto seen. The streets are unpaved, but spacious and airy; the houses high, constructed wholly of stone, brought for the greater part from the sea-shore, and consisting of madrepores and other marine fossils. (Burckhardt [1], early 19th century, Jidda)

In the 1980s, G.R.D. King conducted his research in several regions of the Arabian Peninsula. When he studied the city of Jidda he found that 'the earliest surviving coral house in Jidda today is about 400 years old; the majority are very much more recent' [2, p. 46]. Traditional building materials in Jidda were the mangabi, coral stones, and taklilat, wooden beams. The exteriors were whitewashed by nura, a local plaster. Nura is also used to apply decorations in the exteriors and interiors. The mortar used was brought from the Red Sea coast, where the mangabi was found. These are the materials traditionally used in the Red Sea area; however, the buildings in Jidda are noticeably larger than those of the rest of the Red Sea cities [2, p. 46].

King explained some differences between the early houses of Jidda and the later ones. The early houses had mashrabiyyas, rushan being the local term for them, that were 'of turned wood, like Cairene mashrabiya.' The screens of the rushan became flatter over time in the 

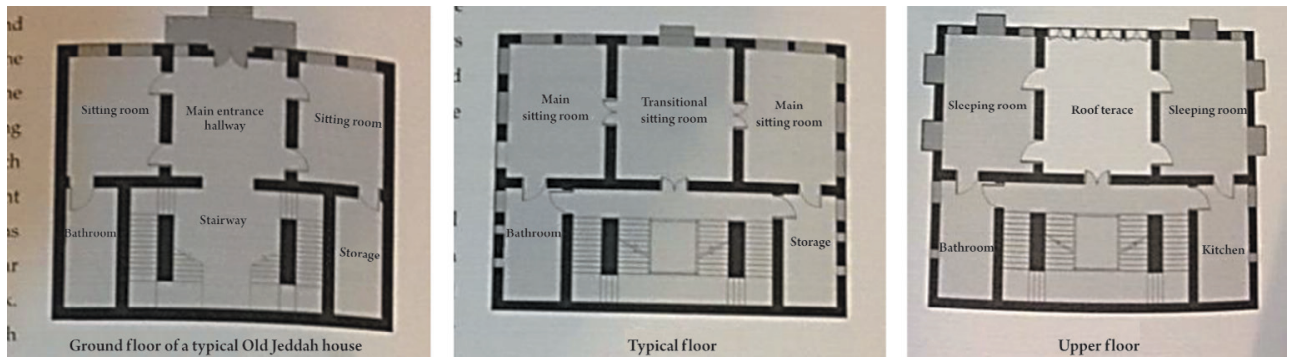

Figure 1: A plan of a typical house in Jidda [3].

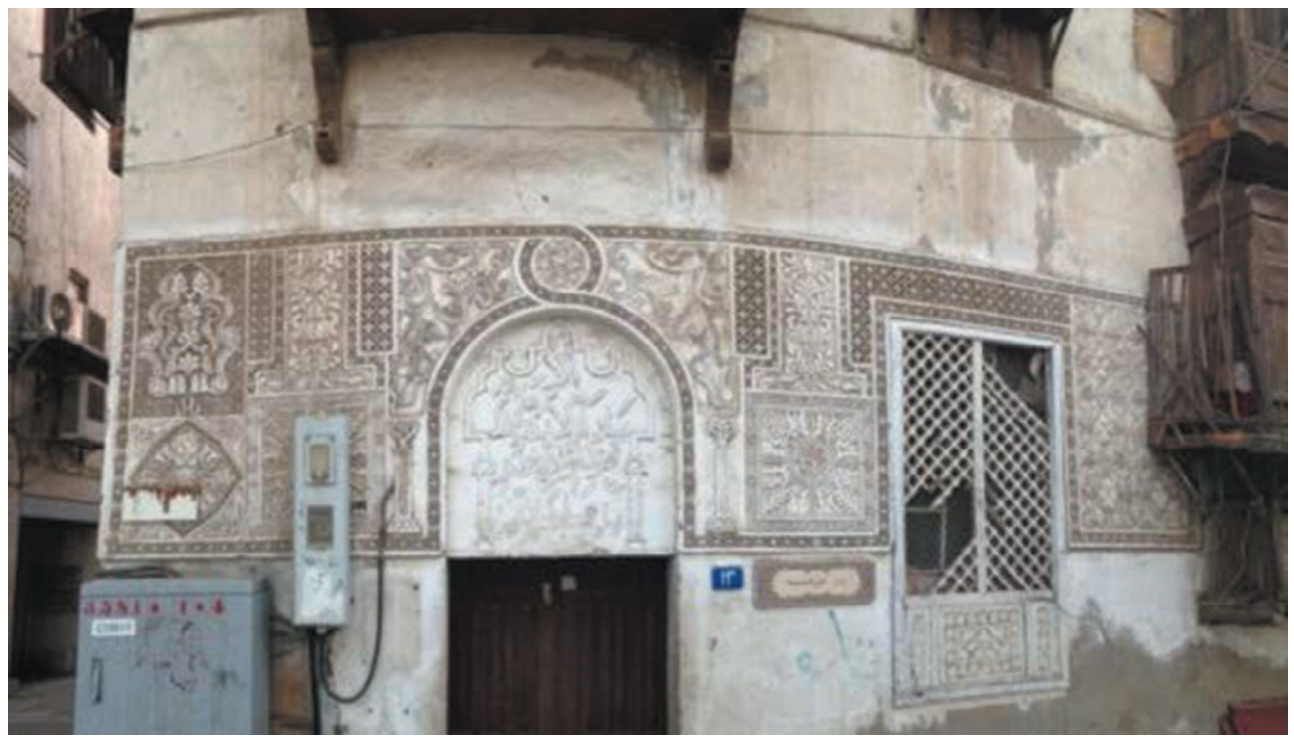

Figure 2: Hazzuga house façade.

later examples. Also, earlier houses were of a maximum of two storeys; later ones had more than that [2, p. 48]. The selected examples in this article are from the later houses in Jidda.

A typical house in Jidda, of three floors (Fig. 1), would have two, maq'ads, formal sitting rooms in the ground floor. The principal sitting rooms, the majlis, are the more private ones and would be in the first floor. The last floor, the roof, would have mabits, which are summer sleeping rooms, and a kitchen, locally known as murakkab. Each floor would have a bathroom, room for bathing, unlike the houses of Cairo in the same era. The typical kind of ornamentation would be those on the wooden rushans and the ornaments created by the nura [3]. A rushan is a projected wooden window with intricate woodwork. It provides ventilation, light and privacy. An extraordinary example of nura ornamentation in Jidda is the one on the façade of Hazzuga house (Fig. 2).

\section{THE AL-JUKHDAR HOUSE}

Al-Jukhdar is a Hijazi family that originally came from Anatolia. I was privileged to meet one of its members, Saliha al-Jukhdar, and ask her about her memories in the al-Jukhdar house in Old Jidda. She said:

I was born in Jidda in the year that witnessed the wars with the Saudis. My parents took me and moved to Sudan the same year because they were worried. We came back when 
we heard that the war was over and Ibn Sa'ud became the ruler of the region. I grew up in a house that was close to the famous al-Jukhdar house. When I became 15 years old, I got married to my cousin and moved to al-Jukhdar house, the famous one.

I asked her about her wedding and whether her family took her permission before the marriage. She said:

Yes, of course, they asked me and I expressed my acceptance in a polite way. My wedding was in the daytime and it ended just after sunset. The women's celebration was at my father's house and the men's celebration was at my husband's; he lived in the house of his grandfather, the eldest of the al-Jukhdar family. After the celebration, my father took me to my in-law's house and I went with my husband to the second floor. That was where we lived in, the al-Jukhdar house. Everything there was pleasant; I really liked the place. My mother gave me her grandmother's wooden box called saisam. It was filled with clothes, fabrics and special kind of pants brought from Aleppo. I still have the saisam.'

She continued telling me what she remembered of the house:

The ground floor was where my father in law received his guests. The roof had the kitchen and slaves used to cook and bake for us every day. We, as a family, gathered in the first floor for almost every meal, especially for lunch. I lived with my husband and his sister Zain in the second floor. There were two staircases in the house. As soon as you reach our floor, you would see a large sitting area called majlis and another space where we used to sit during the day and sleep at night, it was called suffa. I was responsible for cleaning my floor and my clothes. Also, every floor had its bathroom with hot water available. During the warm summer nights, we used to sleep in the roof, and so did many families in Jidda. Because many families lived in this house, we used to divide the roof among us to preserve the privacy of each family even though we were all cousins. The al-Jukhdar family was a conservative one. It was not usual to have friends visiting us or anything like that. I remember that only my mother used to stay with me after I gave birth to my children. She stayed for a while to help me and left.

I asked her whether the house was decorated when she lived there. She replied: 'Yes, the house was beautiful. The ceiling had carved wood and there were pretty chandeliers as well. We had traditional furniture which was the basic sofas pushed against the walls, we called them karawita.'

\subsection{Location}

The al-Jukhdar house is located in mahallat al-Yaman (Fig. 3). It is located in a residential area, but just one block away from the main commercial streets - Gabel and al-'Alawi. The house is located on a corner that leaves its western and southern façades free. Its northern and eastern sides are blocked by neighbouring buildings.

\subsubsection{Date and history}

The owner of the house was Muhammad Nur al-Jukhdar. He built it in the later part of the 1800s [4, p. 214]. The owner was of Turkish origins and he used to manage the mutawwifs of the Javanese pilgrims in Jidda. The mutawwif is a person who guides the pilgrims in their journey. The mutawwif guilds were divided according to the nationality of the pilgrims. 


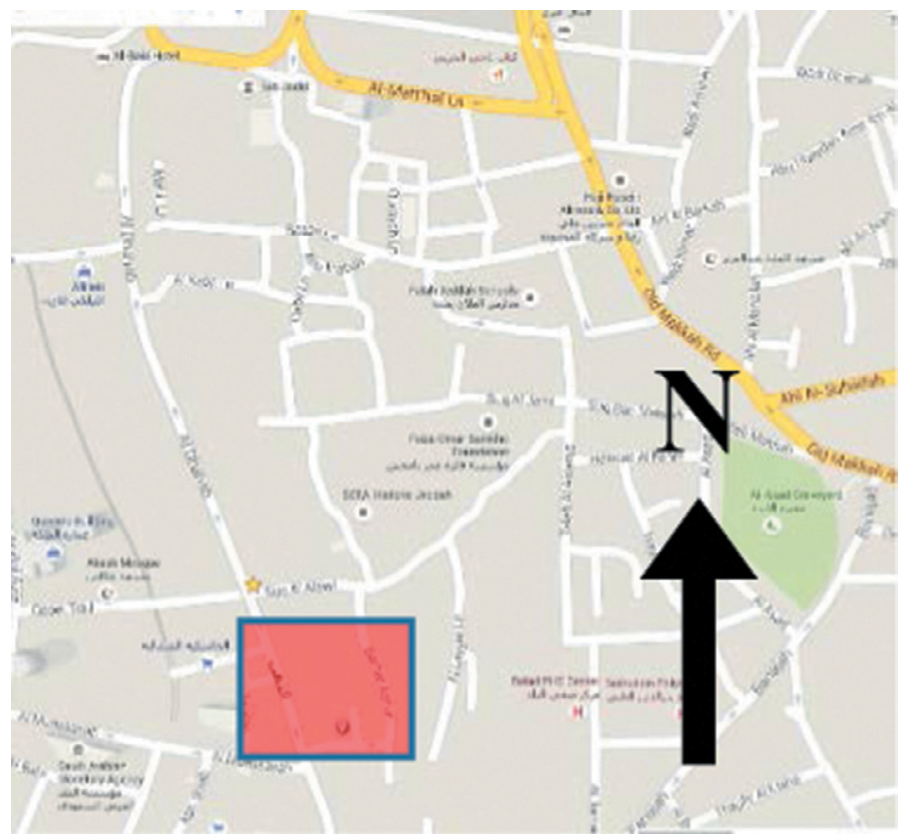

Figure 3: Al-Jukhdar, courtesy Google Maps.

\subsubsection{Architectural analysis}

The al-Jukhdar house consists of a ground floor and three floors above it. It is characterized by the symmetry in its main façade, the western side (Fig. 4). The exterior of al-Jukhdar house is one of the best examples of Jidda's traditional architecture. It is characterized by its large rushans and elaborate plaster ornamentation. The largest rushan is in the middle of the façade and three smaller windows are on each side. Both the rushan and the windows are painted in green, unlike what we would see of similar domestic buildings in Egypt and Syria. Although these were painted in the projects that Jidda's municipality started to give Old Jidda a new face in the 1980s, Burckhardt mentioned in his account that Jidda's rushans were gaudily painted. Therefore, King believed that this repainting actually corresponded to the local traditions observed in the 1800s [2, p. 45].

The entrance of al-Jukhdar house is one of a kind in Jidda (Fig. 5). The wooden door is round arched and it is framed by two other round arches made of the local plaster tradition. The door and the spandrels of the largest arch are filled with floral patterns. On both sides

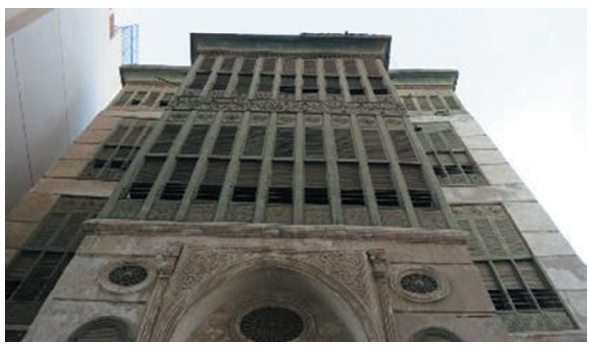

Figure 4: Al-Jukhdar's façade. 
of the entrance there are narrower windows that are round arched as well. The composition is a traditional symmetrical tripartite one. Nura or plaster work in simple geometric patterns is seen on both sides of the door itself (Fig. 6). The other exposed side of the building is the southern one (Fig. 7). The first and second floors have two identical round arched windows and one small rushan. The third floor also has the same small rushan, but there are no two

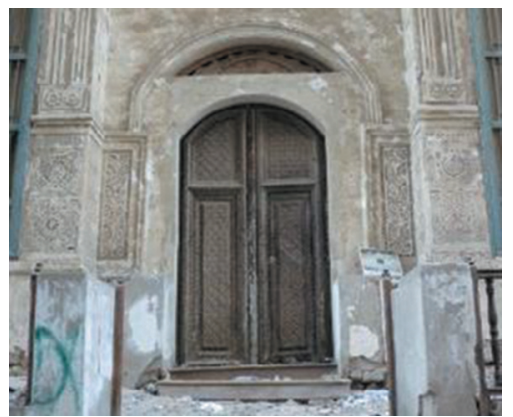

Figure 5: Al-Jukhdar's main entrance.

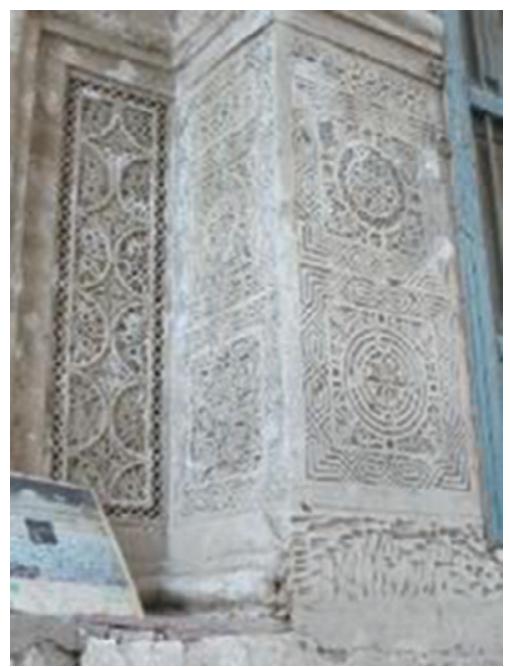

Figure 6: Geometric pattern.

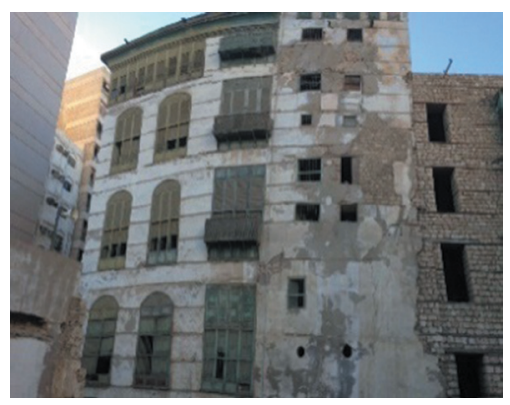

Figure 7: Panoramic view of al-Jukhdar's southern façade. 
identical windows. Instead, there is one big rectangular window. The ground floor has the two identical windows, but a rectangular window on the side. In general, the design is balanced and well studied. Between every stone register and the other we see a narrow wooden beam called takalil that cushions the stones above. It is important to mention that the wood used in such buildings in Jidda was always imported, from India or Southeast Asia [3].

Fortunately, the interior of this house has barely changed. This is unusual in Jidda's houses. For most houses, when their owners left by the second part of the 20th century, they let the rooms of their houses cheaply, mostly to foreign labourers. Therefore, most of Jidda's houses were changed in their interior. What Saliha al-Jukhdar described is still intact.

The house (Fig. 8), has a central lobby known locally as dihliz behind the main door (Fig. 9). It opens to the formal sitting areas, the maq'ads. The interior façade of the dihliz had decorative plaster work in its spandrels. The common features are the vegetal forms and the knotted band design; however, what is unusual in Jidda's plaster work is the calligraphic designs (Fig. 10). According to Saliha al-Jukhdar's account, there was a large chandelier hanging in the middle of this arch. Also, there is an interesting false lambrequin arch, popular in Maghrebi and Andalusian architecture, in the centre of the dihliz leading to the doublestairway system (Fig. 11). The stairways also correspond to Saliha al-Jukhdar's description (Fig. 12).

The first floor and the second floor are almost identical (Fig. 13). Both have a suffa, where the family used to sleep, and two sitting areas, majlis. Each of these rooms has a high ceiling, large windows, fixed seating and built-in shelves or storage (Fig. 14). The central sitting area in the second floor corresponds with Saliha al-Jukhdar's account (Fig. 15). It is a large room with carved wooden ceiling and a place for a central chandelier. Also, there are storage spaces in every floor and a bathroom. Some heavy wooden partitions are used as dividers between the spaces (Fig. 16).

The last floor (Fig. 17), which is the third, did not meet my expectations. It has less open spaces than what Saliha al-Jukhdar described. However, it has a kitchen and some small closed areas, probably for storage. It also has the mabits and a kharja, terrace.

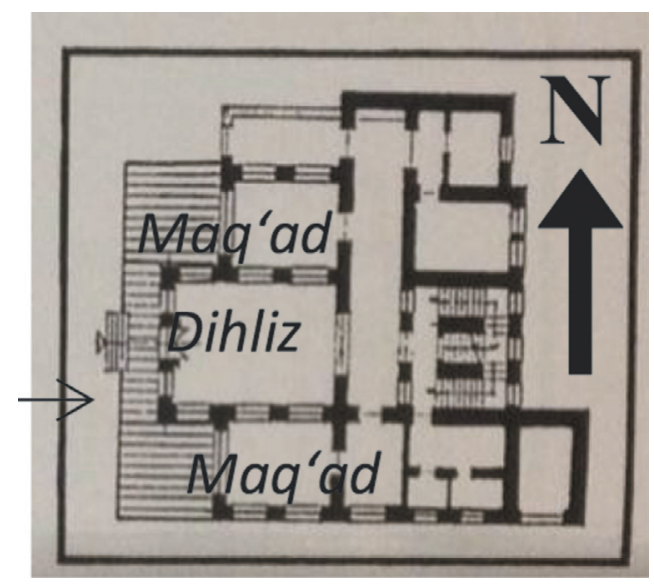

Figure 8: The ground floor plan of the Al-Jukhdar house [4, Fig. 39]. 
Islamic Heritage Architecture 93

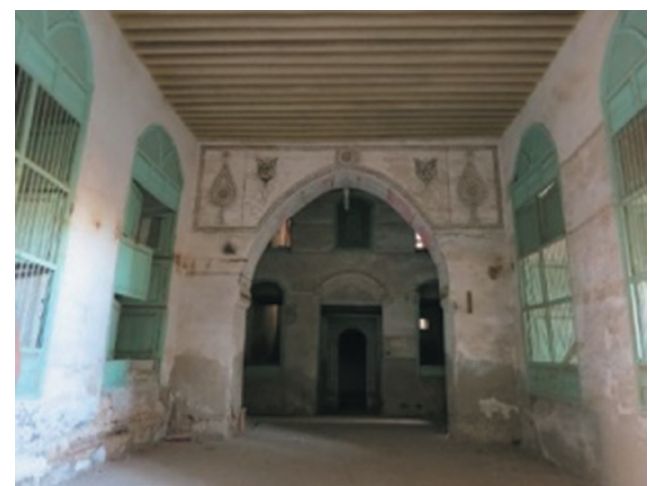

Figure 9: Al-Jukhdar's dihliz.
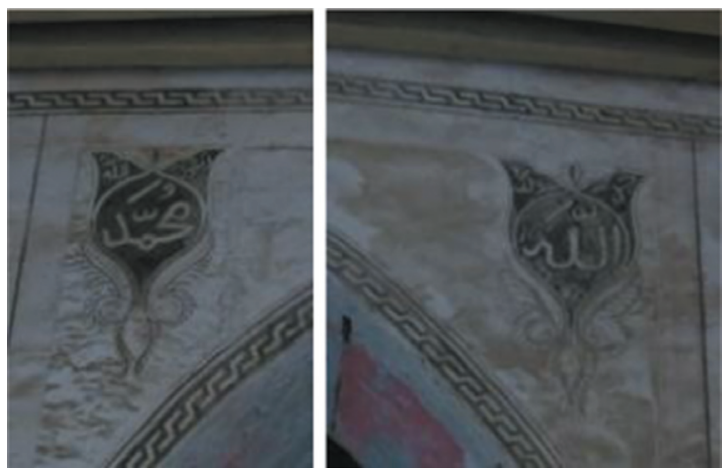

Figure 10: Al-Jukhdar's calligraphic designs.

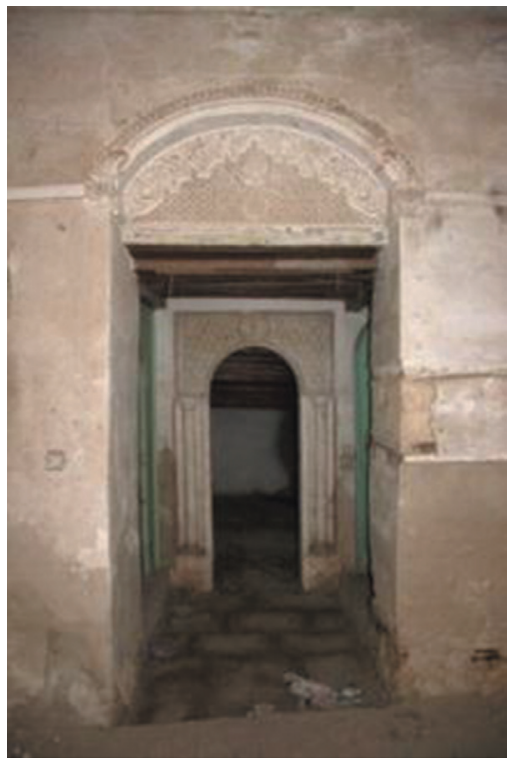

Figure 11: Al-Jukhdar's lambrequin arch. 
94 Islamic Heritage Architecture

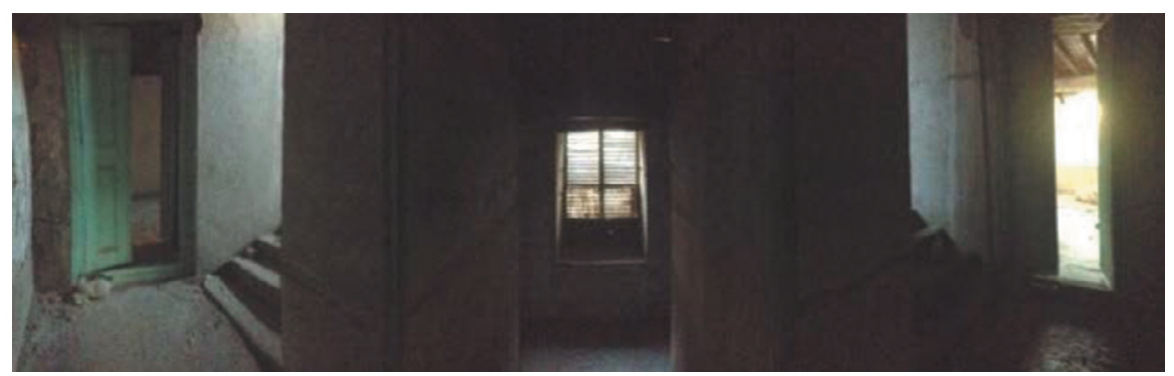

Figure 12: Al-Jukhdar's double stairway.
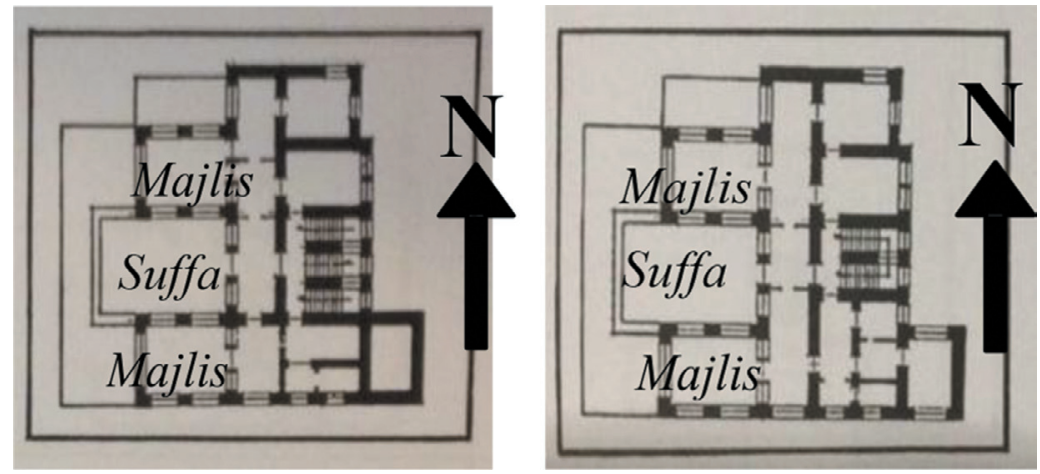

Figure 13: Al-Jukhdar's first floor (left) and second floor (right) [4, Fig. 39].
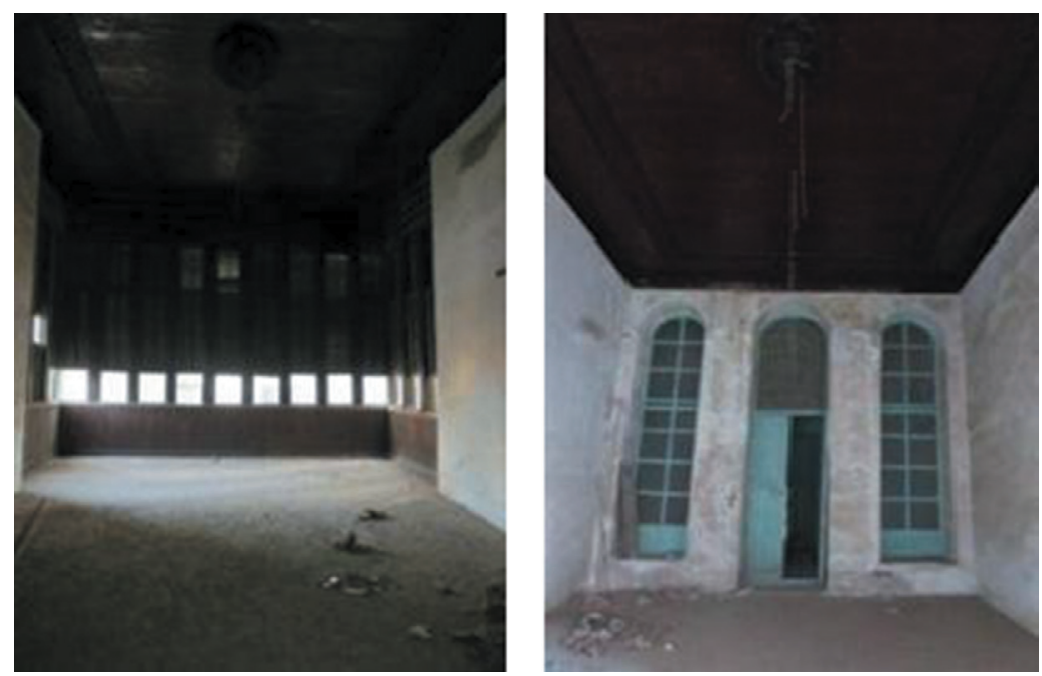

Figure 14: Al-Jukhdar's suffa and majlis, with fixed seating, large windows and storage shelves. 

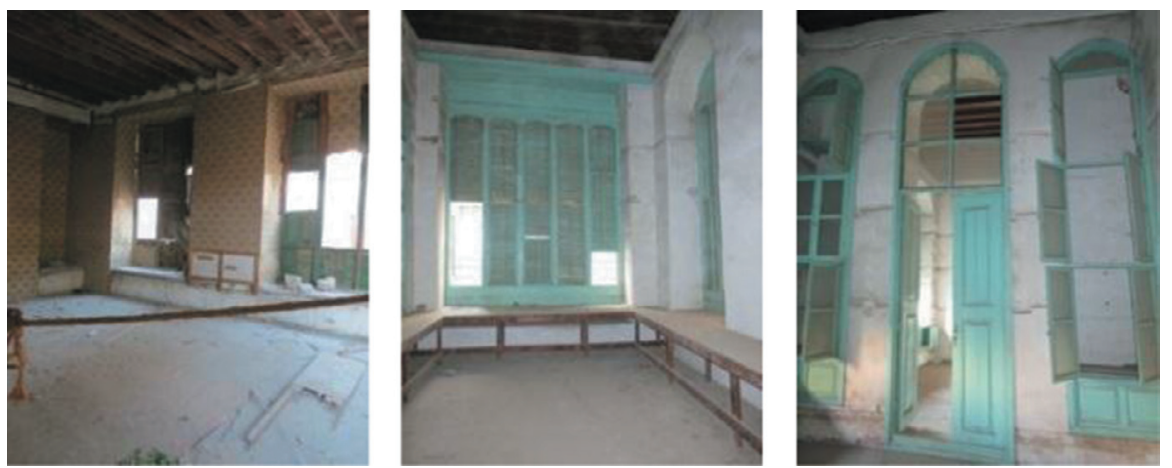

Figure 15: Al-Jukhdar's central sitting area in the second floor.
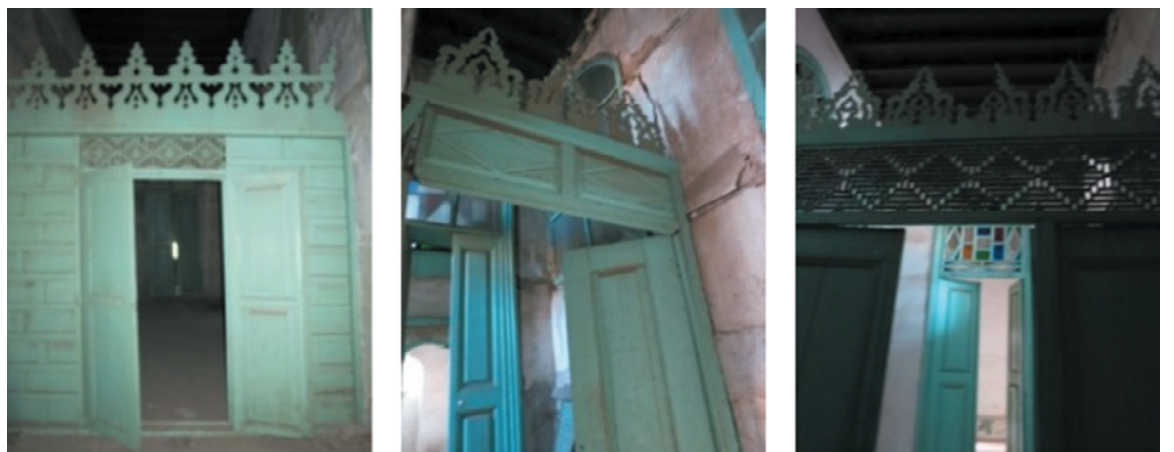

Figure 16: Al-Jukhdar's wooden partitions.

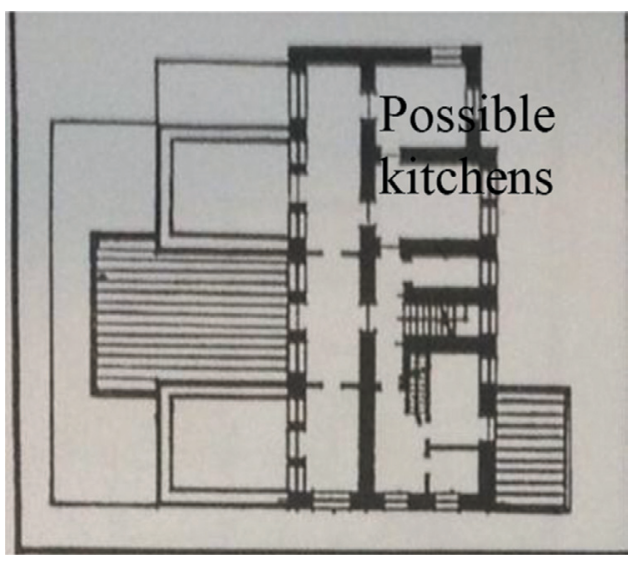

Figure 17: Al-Jukhdar's third floor plan [4, Fig. 39]. 


\section{NUR WALI'S HOUSE}

One would be astonished by the unique façade of Nur Wali's house while passing by at the very crowded Gabel Street. In order to understand this house, I met Zainab Muhammad Nur Wali, or Um Uthman, as she preferred to be called. Um Uthman lived in Nur Wali's house for 15 years after 1964. She told me about her life in that house. At the beginning I asked her about the history and origins of her family; she said:

We are originally Indians. My fourth grandfather, Abd al-Ghani Nur Wali, who was a merchant, moved to the Hijaz about 150 years ago during the time of the Hashemites. However, my ancestors went back to India and again to the Hijaz at the reign of King Abd al-Aziz. They were merchants of spices and Indian rice. The famous house of Nur Wali in Jidda was bought at that time by Abd al-Qadir Nur Wali from Ashur family.

I asked Um Uthman about her early days; she answered:

I was born and raised in Makkah. I studied Qur'an, Arabic and Maths in a kuttab, traditional school, of a Javanese lady. I stopped attending the kuttab when I was nine years old. Then, I learned sewing and knitting, which I really enjoyed. I got married to Abd al-Rahim Abd al-Qadir Nur Wali in year 1384 A.H. (equivalent to 1964 A.D.) when I was 13 years old and moved to live with him in his family's house, the famous Nur Wali house, in Jidda. Our fathers were cousins. My husband was 18 years old when we got married; however, he was very responsible unlike today's youth.

Um Uthman then described the house:

When I moved to the Nur Wali house in Jidda its main entrance was on the side not at its main façade. The ground floor was already transformed into showrooms of the family's different businesses. In addition to rice and spices, they sold ghee and honey. They also had a pharmacy which was called makhzan al-adwiya, the storage of medicines. There was an opening from the middle room of the shops leading to the staircase at the back of the house; however, we rarely used that entrance because it was inside the shop. The side door led to a corridor then the staircase. The house used to have a patio that was used for animals. The stairs led to all different floors of the house. Each floor was divided into two apartments, each was for a family. My father in law, who we called al-sayyid, the master, lived in the most upper floor with his sister. His five sons, including my husband, and one of his grandsons lived in the other floors. The first and second floors were identical and they were for the two eldest brothers. As soon as you reached the floor you would find a long corridor, a toilet and a bathing room on your left-hand side, a suffa, which was an informal sitting room that would be our bedroom at night, then a majlis and finally another sitting room next to it. The toilet was always separated from the bathing room for hygiene reasons. The apartment on the right was larger than the one at the left side of the house. The smaller apartment would also have a toilet, a bathing room, a suffa and only one sitting room. My husband and I lived in the right side of the third floor. This floor was different from the lower two because it had a balcony in the middle, it was beautiful! Also, as soon as you reached the floor you would find a long corridor, one toilet, bathing room, suffa, a sitting room and the balcony, kharja. The upper floor had the mabit, summer bedrooms, and the kitchen. Al-Sayyid lived in that floor. There 
were upper spaces used as laundry rooms, extra mabits and there was a steam domed bath too. All toilets and baths were tiled and renovated with modern technologies few years before my arrival in the house. I was told that the water used to be brought to the house by the saqqa, a person who would distribute fresh water in the city.

I asked Um Uthman about her daily life in Nur Wali's house and what she enjoyed the most; she answered:

My day started just before sunrise. Together with the wives of the other brothers, I would prepare the breakfast while the men were praying at the nearby mosque, masjid al-Mi'mar. Then we, women, would clean up the house, then do the laundry and begin preparing lunch. In the afternoon, we would help our children in their studies and prepare spices. My daughters' school was in al-Mazlum neighbourhood which was 15 minutes away walking. My favourite time of the day was when I worked on my sewing machine in the suffa. It was a blessing that we used to enjoy simple things in life. Every time has its pleasure and I thank Allah for all of His many bounties.

\subsection{LOCATION}

Nur Wali's house is located in mahallat al-Yaman on Gabel Street, the main commercial artery in Old Jidda (Fig. 18). Adnan al-Yafi, a Hijazi historian, described it to me as the Champs-Élysées of Jidda. Gabel Street is located in the middle of the city stretching from the west to the east. Husain ibn Ali constructed it in the early 1900s. In the 1920s, the Gabel family bought it from him, just before the Saudi domination, and covered it. It is known to be the first street in Jidda that was entirely lit by electricity [5]. Nur Wali's house is very close to one of Old Jidda's most popular houses, the house of Nassif.

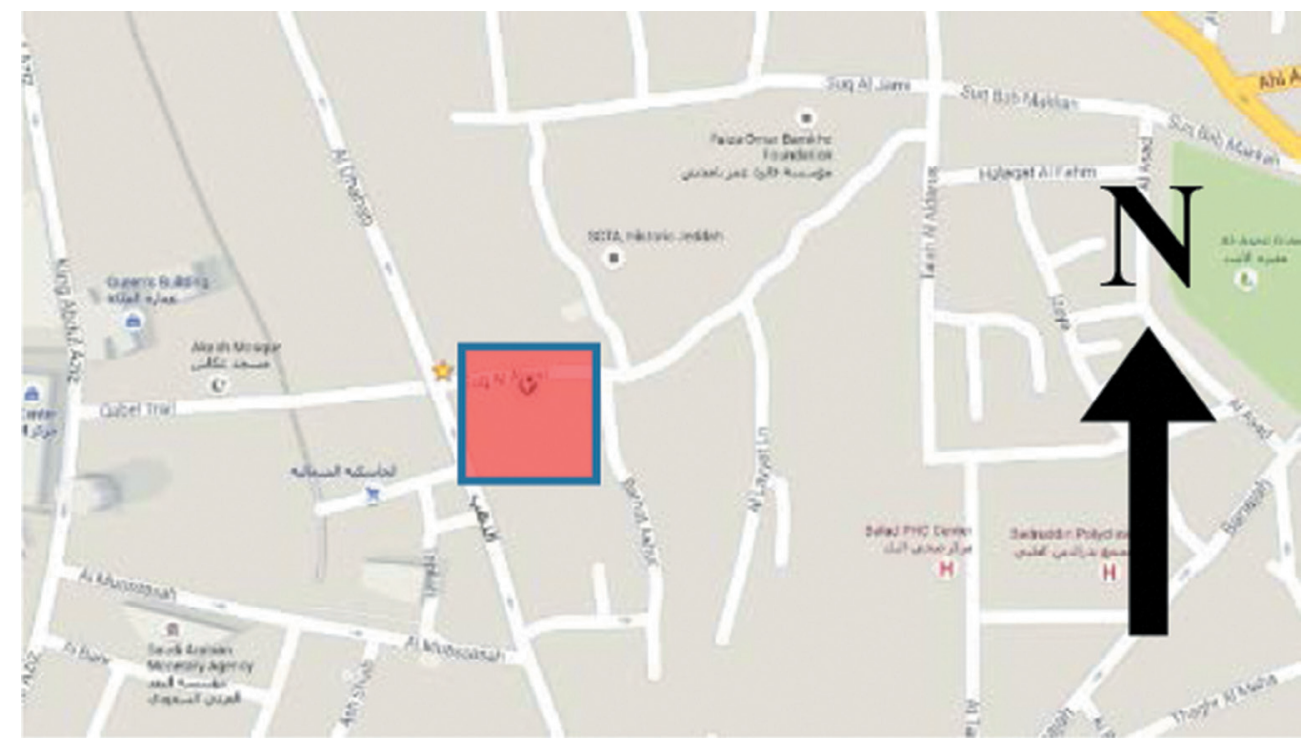

Figure 18: The location of Nur Wali's house, courtesy Google Maps. 


\subsubsection{Date and history}

This house was built in the late 1700s by a famous Hijazi family called al-Sabban. After several years the Ashur family bought it. In the late 1800s, the Nur Wali family bought it from the Ashur family, which is why the house now is known as the Nur Wali house, the name of the last owners. The Nur Wali was Indian merchant family who settled in the Hijaz a long time ago. They were specifically known for selling Indian rice [6]. The building is one of the tallest in Jidda, being six storeys with a magnificent rushan in its main façade.

\subsubsection{Architectural analysis}

There is no doubt that Nur Wali's house has one of the most elaborate façades in Old Jidda (Fig. 19). It has not only a large dominating rushan but also a unique symmetrical one. There is a great diversity in the ornamentation of the rushan itself. It is important to mention that the rows of rushan do not correspond to the number of storeys in this house. This is a common feature in many houses in Old Jidda. The rushan would deceive a viewer and make it look like a four-storey building, but it is in fact six storeys. The middle register of the rushan complex of Nur Wali's house takes an elongated conical form that is uncommon to see in the city. Then, on both sides of the middle part we see almost two identical rushan forms to the left and right. Most of the ornamentation is geometric, alternating between usual mashrabiya diagonal arrangement and traditional mangur, which is a Hijazi term for intertwining wood to form geometrical patterns used as screens in windows (Fig. 20).

The main entrance of the house used to be in the main façade, the northern. The entrance that the family used until they permanently left was on the house's western façade (Fig. 21). This façade also has elaborate diverse rushans. The southern façade of the building has much changed; it used to open into a small patio, which is unusual in traditional houses in the city [4, p. 282]. The interior follows Um Uthman's description. It used to have the same arrangement as in other Jidda's houses. However, the ground floor was changed to shops as mentioned above. Also, what is different about this house is that it does not have a uniform

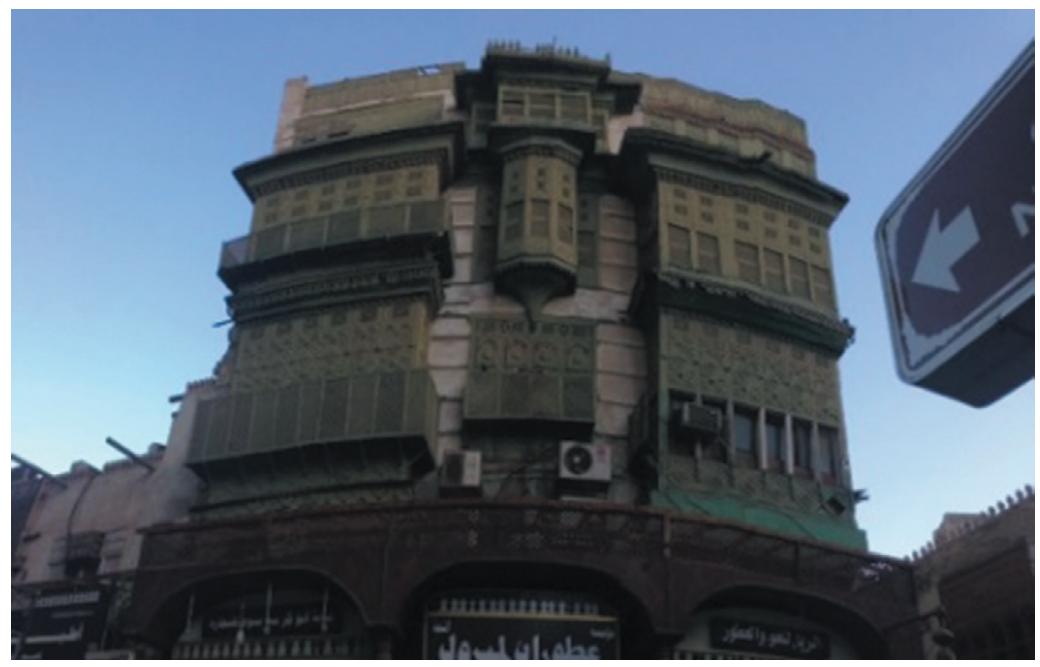

Figure 19: Nur Wali’s façade. 


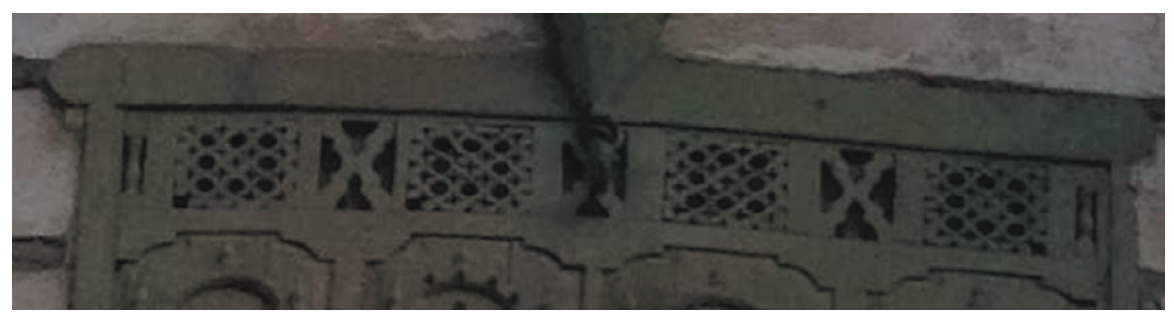

Figure 20: Nur Wali's mangur wood work.

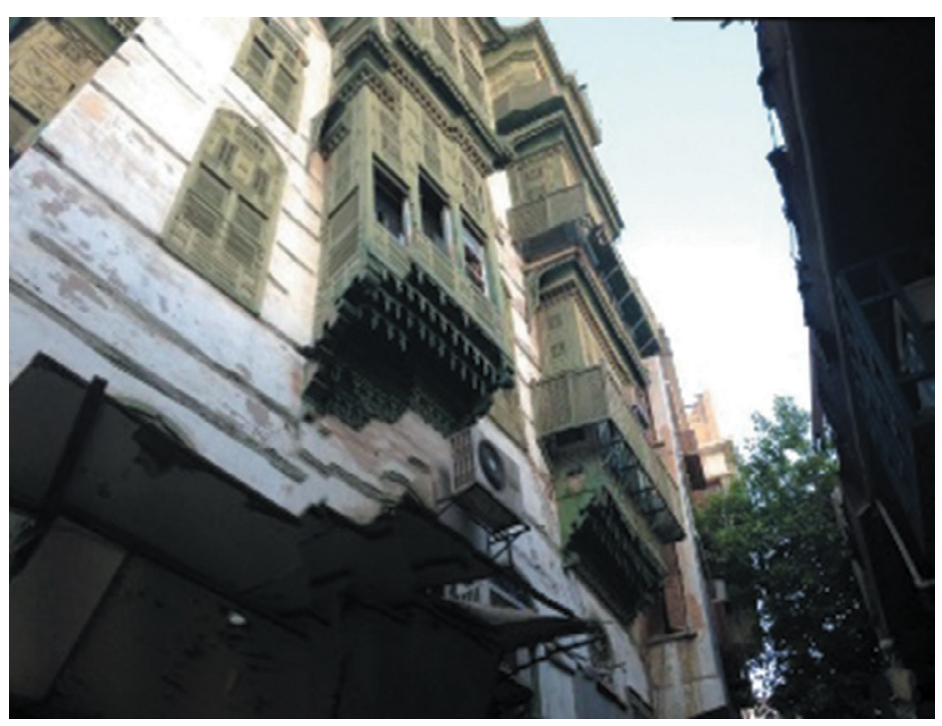

Figure 21: Nur Wali's western façade.

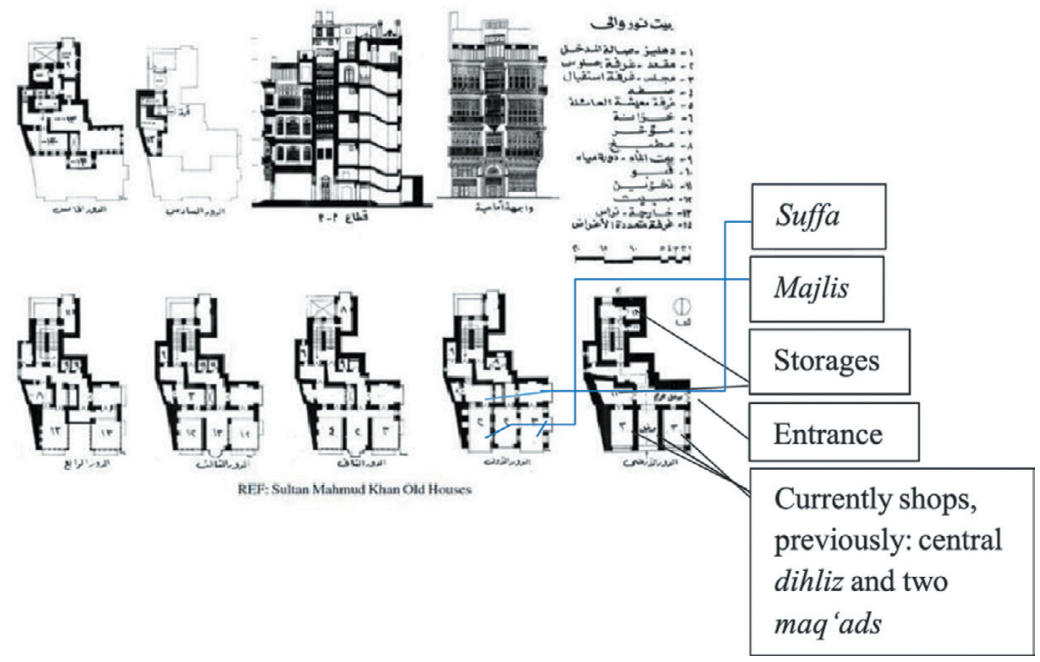

Figure 22: Plan of Nur Wali's house [7]. 
rectangular plan (Fig. 22). Probably the main entrance used to lead to the dihliz, which in turn leads to two maq'ads on the sides. The services are to the back of the house. The first two floors are almost identical with the suffa and the majlis for guests. These two floors are offices for the family's business today. The third floor has the same arrangement, but with a kharja, terrace. The upper floors have the mabits, kitchen, toilet, bathing room and a steam room. The floors were divided into apartments to suit the large number of family members. The interior was lavishly decorated with intricate carved wood and stucco.

The previous selected buildings were built between the 1700s and the 1800s, which was in the late Ottoman or Hashemite periods. Development, deterioration and alteration occurred throughout their history. There are many common features that one can find in these buildings. Symmetry is a value that builders in Jidda admired and constantly repeated in various architectural elements. Building materials show no variations; always the mangabi coral stone with wooden beams and nura. The oral history that was documented through interviews with people who lived in these houses showed a lot. Extended families lived in these houses. Although they shared a lot of spaces and facilities within the house, they preserved their privacy via different ways, partitioning and dividing. The way in which people used their spaces was documented through the interviews as well. The interior spaces are more meaningful when one understands how they were used. The rapid change that the city of Jidda witnessed in few years altered the urban fabric, architectural elements and social priorities. With the oil boom people left Old Jidda to expand in its suburbs and beyond. New building technologies and materials changed the shape of the buildings and created a diversion from the traditional style. Hence, society followed that change.

\section{ACKNOWLEDGEMENTS}

The buildings discussed in this paper were part of my master's thesis supervised by Dr. Bernard O'Kane. Here, they have been updated and developed.

\section{REFERENCES}

[1] Burckhardt, J.L., Travels in Arabia, Frank Cass \& Co. Ltd: London, pp. 9-10, 1968.

[2] King, G.R.D., The Traditional Architecture of Saudi Arabia, I.B. Tauris: New York, 1998.

[3] Adas, A., Sarouji, F. \& Telmesani, A., Old Jeddah: A Traditional Arab Muslim City in Saudi Arabia, King Fahd National Library: Jeddah, p. 14, 2009.

[4] Ahmad, S.M.A., Imarat al-dur al-uthmaniya al-baqiya fi madinat Jidda dirasa atariyya mimariya ma mathilataha fi madinat Rashid, MA Thesis, Cairo University: Cairo, p. 214, 2008.

[5] Diyab, M.S., Jidda al-tarikh wa al-haya al-ijtimaiya, Dar al-Ilm: Jidda, p. 71, 2003.

[6] Al-Muabadi, M.M., al-Nashat at-tijari limina Jidda khilal al-hukm al-uthmani al-thani 1256-1335 A.H. 1840-1916 A.D, al-Nadi al-Adabi: Jidda, p. 216, 1993.

[7] Khan, S.M., Jeddah Old Houses: A Study of Vernacular Architecture of the Old City of Jeddah, S.M. Khan: Jidda, p. 87, 1981. 